\title{
A NOVEL METHOD FOR MONITORING URBAN DEW CONDENSATION AND ITS APPLICATION
}

\author{
Yingying Xu, Hui Zhu, Xuejing Sun, Qingling Meng
}

\begin{abstract}
Dew is crucial moisture input for the water balance of urban ecosystems. Dew, which is an important environmental factor of urban ecosystem, can be easily absorbed by plant leaves and provide nutrients (N, P, and K) to plants. Moreover, dew formation is important in air purification. However, few internationally accepted standard methods or instruments are currently available for measuring dew amount in urban ecosystems because of the small dew amount. In order to accurately measure the night water vapour condensation and evaluate the effects of surface hardening to near-surface water cycle, this study monitored dew condensation and combined dew with leaf area index, and a novel method was proposed for monitoring and calculating dew amount in different underlying surfaces in urban ecosystems. The Changchun City in China was considered as an example and the proposed method was used to observe dew condensation in different functional areas of the city during the frost-free period (April 2016 to October 2016). Finally, the main meteorological factors affecting dew condensation were analyzed by summarizing the rule of vapour condensation; moreover, dew intensity and annual dewfall of different landscapes were obtained. Results indicate that greenbelt landscapes are important sites for dew deposition. The landscapes of dew intensity, in descending order, are greenbelt landscape, bare landscape, and road landscape $(P<0.01)$. Relative humidity is the main factor affecting water vapour migration. Dewfall amounts in the greenbelt, road, and bare landscapes are $61.43,0.56$, and $1.23 \mathrm{~mm}$, respectively. The annual dewfall is 22.98 $\mathrm{mm}$ in Changchun according to the proportion of each landscape. The dew-monitoring method system in urban area is improved and the wet deposition from vapour condensation of different surfaces underlying at night is added. The method provides theoretical reference for further research on revealing the near-surface water cycle.
\end{abstract}

Keywords: dew intensity; dewfall; landscape; urban ecosystem

Nova metoda za praćenje kondenzacije rose u gradu i njezina primjena

Izvorni znanstveni članak

Rosa predstavlja unos vlage bitan za održavanje razine vode gradskih ekosustava. Rosu, koja je važan ekološki faktor gradskih ekosustava, lišce biljaka lako apsorbira i tako se opskrbljuje hranjivim tvarima (N, P i K). Osim toga, stvaranje rose važno je u pročišćavanju zraka. Ipak, ima malo internacionalno prihvaćenih standardnih metoda ili instrumenata trenutačno raspoloživih za mjerenje količine rose u urbanim ekosustavima, zbog male količine rose. U svrhu točnog mjerenja kondenzacije vodene pare noću i procjene učinaka stvrdnjavanja površine na tokove vode blizu površine, u radu se prati kondenzacija rose i kombinira rosa s indeksom površine lista te se predlaže nova metoda za praćenje i izračunavanje količine rose u različitim površinama urbanih ekoloških sustava. Grad Changchun u Kini uzet je kao primjer i predloženom metodom se promatrala kondenzacija rose u njegovim različitim funkcionalnim područjima u razdoblju u kojem nema smrzavanja (travanj 2016. do listopada 2016.). Konačno su se analizirali glavni meteorološki faktori koji utječu na kondenzaciju rose sumirajući pravilo kondenzacije vlage; uz to, dobio se intenzitet rose i njezina godišnja količina u različitim krajolicima. Rezultati pokazuju da su područja zelenog pojasa važna mjesta za nakupljanje rose. Redosljed krajolika po intenzitetu rose: područje zelenog pojasa, goli krajolik i krajolik s cestom $(P<0.01)$. Relativna vlažnost je glavni čimbenik od utjecaja na promjenu količine vodene pare. Količine rose se smanjuju idući od zelenog pojasa do golog krajolika i ceste i iznose $61.43,0.56$, i $1.23 \mathrm{~mm}$. Prema omjeru za svaki krajolik godišnja količina rose je u Changchunu $22.98 \mathrm{~mm}$. Sustav za mjerenje količine rose poboljšan je u urbanim dijelovima i dodana mu je količina dobivena kondenzacijom pare noću s različitih površina. Metoda daje teoretske reference za dalje istraživanje o vodenim tokovima blizu površine.

Ključne riječi: intenzitet rose; krajolik; rosa; urbani ekosustav

\section{Introduction}

Dew condensation is a common weather phenomenon. Dew is easy to be absorbed by plant leaves and can add to and regulate the leaf moisture at night [1]. Moreover, dew formation can maintain canopy layer moisture and reduce the plant transpiration. Dew provides nutrients $(\mathrm{N}, \mathrm{P}$, and $\mathrm{K})$ to plants [2, 3]. During dew formation, the small aerosol in the atmosphere is the condensation nucleus and is important in air purification [4]; furthermore, dew can reveal air pollution status and act as an air quality indicator $[5,6]$. Accurate measurement of dew condensation quantity is important, and problems involving dew-monitoring methods have become the focus of domestic and overseas studies.

Numerous studies on dew observation have been conducted, but they were mostly in arid and semiarid regions [2, 7, 8]; moreover, a handful of studies have focused on selva, meadow, and wetland environments [911]. Compared with other precipitation forms, dew formation depends on local weather conditions and the physical characteristics and surrounding environment in terms of radiation, thermodynamics, and aerodynamics.
Therefore, the dew monitors used in different ecosystems are different. For instance, micro-lysimeters or intelligent soil moisture meters are used in desert areas to measure dew amount [12], and plastic sheets are used in rainforest areas to monitor dew condensation [13]. City dew, as an important source of condensation water and humidity, has received increasing interest in recent years [14-16]. Lekouch et al. [17] and Beysens et al. [5] used prototype condensers that were covered with an active substrate (foil) constructed with a film of low-density polyethylene containing infrared-emitting minerals $\left(\mathrm{TiO}_{2}\right.$ and $\left.\mathrm{BaSO}_{4}\right)$ in the atmospheric window and non-soluble surfactant that rendered the surface hydrophilic, to obtain additional dew for use as drinking water. This method accelerated the vapor condensation but could not simulate the real situation of dew formation in urban environments. Galek et al. collected dew from Wroclaw City in Poland, compared the dew and rain chemical characteristics, and found that the ion concentrations in dew are significantly higher than those in rain [18]. Nevertheless, they did not monitor the dew amount. Xu et al. analyzed the dew water quality during haze and normal periods in the Changchun City in China and found dew to be condensed in 
underlying surfaces and that it has an increased ion concentration $\left(\mathrm{F}^{-}, \mathrm{CL}^{-}, \mathrm{SO}_{4}{ }^{2-}, \mathrm{NO}_{3-}, \mathrm{NH}_{4}^{+}, \mathrm{Na}^{+}, \mathrm{K}^{+}, \mathrm{Ca}^{2+}\right.$, $\left.\mathrm{Mg}^{2+}\right)$ ). The ion concentration was 3.01-9.32 times higher than the levels during normal periods [19]. However, this study did not calculate the true amount of dew. The preceding research mainly collected dew water and analyzed the water quality of dew but did not measure the dew amount. Ye used synthetic velvet to measure dew intensity in the different landscapes of Guangzhou City, China [20]. However, the same monitor was used for measuring dew in different landscapes of the city, and the dew water study monitored the daily dew per unit area with no concern of the annual dewfall.

Therefore, few internationally accepted standard methods or instruments are available for measuring dew amount in urban ecosystems. The rapid development of cities has made urban landscape patches complicated. Different surfaces highly influence dew formation and existing methods use the same monitor to observe dew condensation in different landscapes (such as greenbelt and road), thereby leading to large human error in the dew-monitoring process. Moreover, dew condensation in an entire urban system cannot be measured. Existing dew monitoring methods are confined to a single period of dew condensation, which cannot evaluate the dew amount in a particular period. Therefore, a method for monitoring and calculating the dew amount in urban ecosystems should be proposed. This study observed the water vapour condensation in different landscapes in Changchun City in China during the frost-free period (April to October) in 2016 and proposed a method to monitor and calculate urban dew condensation. The aim of this study was to determine the dew condensation characteristics in different landscapes and further improve upon the standard method for dew observation in urban ecosystems.

The remainder of this study is divided into several sections. Section 2 describes the location and method of dew monitoring, including the formulas for calculating annual dewfall. Section 3 presents the use of the method of monitoring dew intensity and dewfall, the analysis of the factors that influence the water vapour condensation near the ground, and comparison of the dew intensity and dewfall in different ecosystems. Finally, Section 4 concludes the study.

\section{Materials and methods \\ 2.1 Test bed for rock fragmentation}

Changchun $\left(125^{\circ} 10^{\prime} \mathrm{E}\right.$ to $125^{\circ} 30^{\prime} \mathrm{E}, 43^{\circ} 40^{\prime} \mathrm{N}$ to $\left.44^{\circ} 10^{\prime} \mathrm{N}\right)$ lies in the Northeast of China. The study was conducted in the frost-free season from April 1 to October 30 in 2016. As shown in Figure 1, the distance between each type of landscape plot exceeds the radius of Changchun City. Dew condenses on surfaces near the ground level. The greenbelt (including the plants in the community, in the park, and on the roadside), asphalt road, and unused bare land were selected as the representative areas of Changchun City.

Changchun is in a semi-humid monsoon climate zone with a mean annual temperature of $4.8{ }^{\circ} \mathrm{C}$ and annual precipitation of $522-615 \mathrm{~mm}$. The experimental area is rainy in summer, with high humidity; moreover, due to its cloudless nights and windless days, Changchun is suitable for dew condensation. During autumn, the weather is sunny, with high humidity, high temperature difference, and low wind speed. The climate conditions are thus suitable for dew condensation.

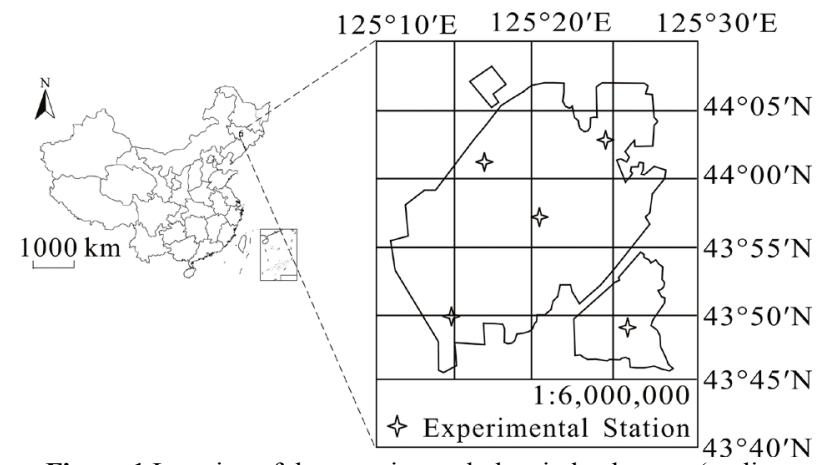

Figure 1 Location of the experimental plots in landscapes (outline represents the city boundaries)

\subsection{Methodology}

It is a process of phase transformation resulting from nocturnal radiative loss of heat from underlying surfaces in conjunction with temperature dropping below the dew point of ambient air. Dew condenses in the near-surface range of $0-3 \mathrm{~m}$, and the dew condensation areas of the study included greenbelt, asphalt road, and unused bare land. Poplar wood sticks, asphalt blocks, and soil blocks were selected as monitors that were deployed in the greenbelt, road, and bare landscapes. The poplar wood stick was polished with a size of $20 \times 4.0 \times 4.0 \mathrm{~cm}$ (length $\times$ width $\times$ height). The size of asphalt block was $15 \times 15 \times$ $1.0 \mathrm{~cm}$ (length $\times$ width $\times$ height). The soil was set in an aluminum can with dimensions of $5.0 \times 5.0 \times 5.0 \mathrm{~cm}$ (diameter $\times$ diameter $\times$ height). The aluminum can was cylindrical with no cover on the upper surface.

The poplar wood stick and asphalt block were placed in a sealable plastic box, and the moisture around the aluminum box filled with soil was cleaned. The monitors were weighed daily at half an hour after sunset with an electronic balance (accuracy within $0.001 \mathrm{~g}$ ) and recorded. For each experimental plot in the greenbelt landscape, the monitors were set on the plant canopy. For the road and bare landscapes, the monitors were set on the ground. For each plot, monitors were positioned half an hour after sunset. The monitors were kept in each plot until the next sunrise. These monitors were gathered half an hour before sunrise and weighed again. Moreover, the leaf area index (LAI) of plants was measured daily using a LAI-2200C Plant Canopy Analyzer. Dew is difficult to distinguish from rain, thus the dewfall was recorded as zero for the night if rainfall event occurred during the measuring period. This method can be used to monitor daily dew intensity of urban ecosystems and calculate annual dewfall

Dew intensity $(I)$ is the amount of dew that condenses on all terrestrial objects, including plants and soil, in a unit land area in one night. Dew intensity represents the capability for condensation. The unit counts are represented in millimeters.

The dew intensity for each experimental plot is calculated as follows: 


$$
I_{i q}=\frac{10 \times\left(W_{i r}-W_{i s}\right)}{S_{i}}
$$

The dew intensity for each landscape is calculated with the following formula:

$$
I_{i d}=\overline{I_{i q}}
$$

where $i$ is the type of landscapes with an $i$ of 1 representing greenbelt, an $i$ of 2 representing road, and an $i$ of 3 standing for bareland; $I_{i q}$ is the dew intensity $(\mathrm{mm})$ for each plot; $I_{i d}$ is the dew intensity $(\mathrm{mm})$ for each landscape; $W_{i r}$ is the weight of the monitor before sunrise $(\mathrm{g}) ; W_{i s}$ is the weight of the monitor after sunset $(\mathrm{g}) ; S_{i}$ is the surface area of the monitor $\left(\mathrm{cm}^{2}\right)$; and 10 is the conversion factor.

Dewfall $(D F)$ is the amount of dew that condenses on all terrestrial objects, including plants and soil, in a unit land area in a particular period. Dewfall represents the quantity of dew amount. The unit counts are presented as millimeters.

Dew days ( $D_{d}$; units: days) are the number of dew events that occur in a particular period.

Monthly dewfall in road and bare landscapes is calculated as follows:

$$
D F_{2 / 3 m u}=\sum_{d=1}^{D_{d}} I_{2 / 3 d}
$$

Monthly dewfall in the greenbelt landscape is calculated as follows:
$D F_{1 m u}=\sum_{d=1}^{D_{d}} 2 \times L A I_{1 d} \times I_{1 d}$

Annual dewfall in each landscape is calculated with the following formula:

$$
D F_{a i}=\sum_{u=1}^{n} D F_{i m u}
$$

Annual dewfall in urban area is calculated with the following formula:

$D F_{a}=\sum A_{i} D F_{a i}$

where $D F_{\text {ium }}$ is the monthly dewfall $(\mathrm{mm}) ; D_{d}$ is the dew days (day); $L A I_{1 d}$ is the $L A I$ in each day $\left(\mathrm{cm}^{2} / \mathrm{cm}^{2}\right) ; D_{a i}$ is the annual dewfall for each landscape $(\mathrm{mm}) ; 2$ is the coefficient of leaf side; $n$ is the number of month; $A_{i}$ is the proportion of each landscape in the urban area (\%); and $D F_{a}$ is the annual dewfall in the urban area $(\mathrm{mm})$.

\subsection{Meteorological factor monitoring}

Dew is a natural phenomenon under the influence of microclimate and its condensation condition is weak in relation to the changes in distant weather factors. Therefore, meteorological factors were recorded at each experimental plot. The daily meteorological factors, including air temperature $\left({ }^{\circ} \mathrm{C}\right)\left(T_{a}\right)$, dew point temperature $\left({ }^{\circ} \mathrm{C}\right)$, relative humidity $(\%)(R H)$, wind speed, and rainfall $(\mathrm{mm})$, were measured in $10 \mathrm{~min}$ intervals during the condensation time via the MILOS 520 Weather Station (Finland) at $1.7 \mathrm{~m}$ above ground level (accuracy $= \pm 0.1$ ${ }^{\circ} \mathrm{C}$ and $\pm 2 \% R H$ ) (Fig. 2).
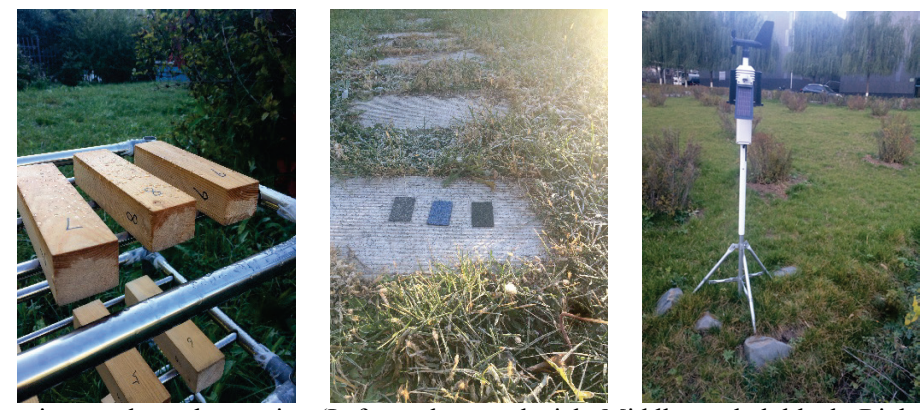

Figure 2 Dew monitors and weather station (Left: poplar wood stick; Middle: asphalt block; Right: weather station)

\section{Results and discussion 3.1 Dew intensity}

This section discusses the dew days and the dew intensity of different landscapes with seasonal changes in urban ecosystems based on the dew intensity calculation formulas (1 and 2) and dew observation method mentioned in Section 2.2. The dew days were 13, 18, 15, 24, 23, 16, and 20 from April to October with 129 dew days during the experimental period. The number of dew days accounted for $61.4 \%$ of the frost-free season. The dew intensity for each landscape is displayed in Fig. 3. Statistical analyses indicated that the dew intensities of greenbelt, bare land, and road landscapes all followed a normal distribution pattern. The dew intensity of different landscapes was analyzed using one-way ANOVA, and the significance limit was set to $P<0.05$. Least significant difference was used to determine the significant differences between each group of dew intensity. The highest dew intensity was observed in the greenbelt landscape, followed by the bare landscape, then the road landscape $(P<0.01)$. As to the greenbelt area, the dew intensities in July, August, and September were significantly higher than those in other months $(P<0.01)$, and the dew intensities in July were the highest in the road area $(P<0.01)$. By contrast, the dew intensity did not show differences among months in the bare land plots $(P>0.05)$. 


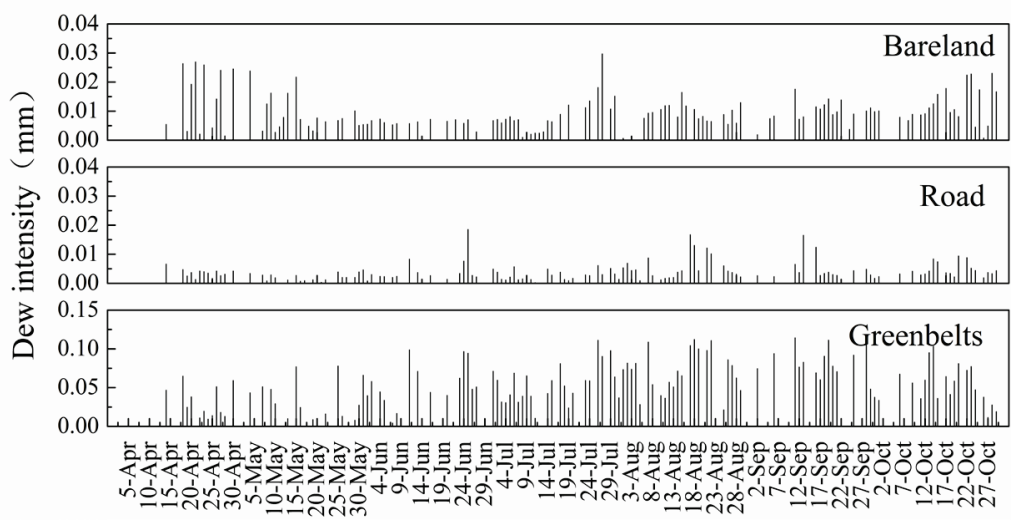

Figure 3 Variation in dew intensity in greenbelt, bare land, and road landscapes in 2016

\subsection{Meteorological parameters}

The differences in dew intensity in the greenbelt, road, and bare land plots were influenced by meteorological factors. Dew formation has been previously reported to be influenced by the meteorological parameters of different regions. Relative humidity, air temperature, cloudage, and wind are responsible for dew intensity $[7,15,21]$. The factors for the different underlying surfaces in the same city, such as the same cloudage, wind speed, and wind direction, are negligible. Relative humidity and temperature are the most important factors controlling dew production. The results showed that urban dew intensity increased with increasing relative humidity, and this was consistent with other investigations.

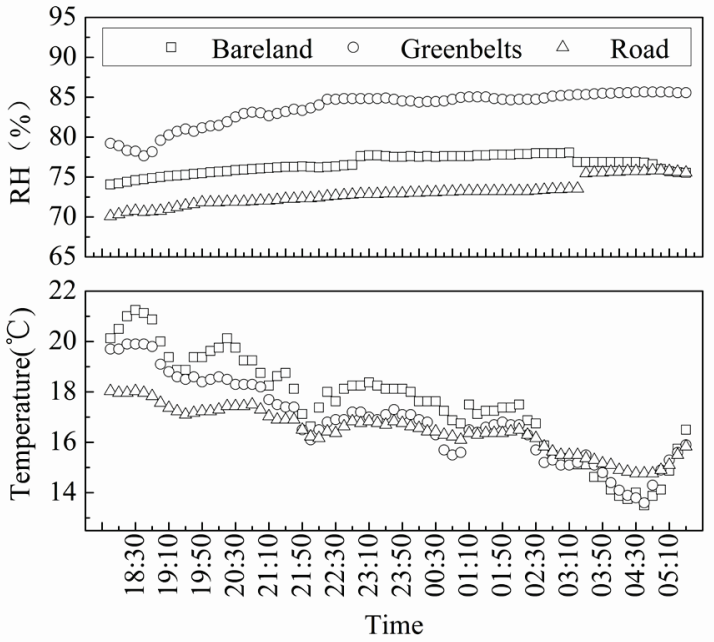

Figure 4 Variation in temperature and $R H$ from 18:00 of July 25 to 5:30 of July 26 in the greenbelt, road, and bare landscapes during 2016

For example on July 252016 to July 26 of 2016 (Fig. 4), the dew intensity was higher in the greenbelt landscape than in the road and bare landscapes, and this might be attributed to the high average relative humidity in the greenbelt landscape more than in the road and bare landscapes. The nocturnal temperatures of landscapes did not exhibit any differences $(P>0.05)$, but the relative humidity in the greenbelt landscape was higher than in the road and bare landscapes $(P<0.01)$. The differences in dew intensity among landscapes could be explained by the differences in relative humidity. Relative humidity is an important factor for dew condensation.

\subsection{Dewfall}

This section analyzes the dew condensation in different landscapes of the urban ecosystem based on the dewfall calculation method mentioned in Section 2.2 (Eqs. (3)-(5)) and further measures the annual dewfall in the near surface of the city. Variations in dewfall and LAI in each landscape from April to October in 2016 are shown in Fig. 5.

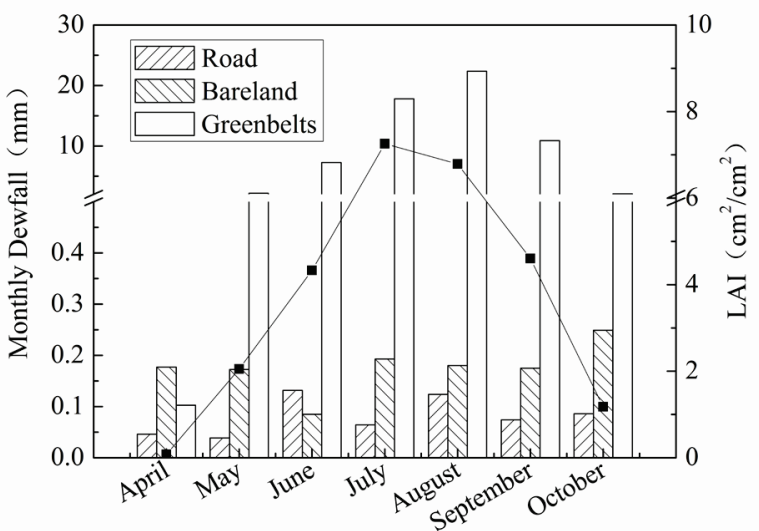

Figure 5 Variation in dewfall and $L A I$ in greenbelt, road, and bare landscapes in 2016

Dewfall in the greenbelt landscape was higher than in the other landscapes. Dewfall levels peaked in the greenbelt and bare landscapes during July and August; in the road landscape, the levels were minimal, and the change was not apparent. Dew is important in the water balance of the greenbelt landscape and the dewfall amounts in July and August were 17.79 and $22.36 \mathrm{~mm}$, which accounted for $13.67 \%$ and $18.56 \%$ of the rainfall in the same period, respectively. The main reason for the significant dewfall in the greenbelt landscape was the high $L A I$. The $L A I$ of the greenbelt landscape was higher than those in other landscapes within the same period. Moreover, dense plant leaves had considerable space on which vapor could accumulate. In 2016, the annual dewfall amounts in the greenbelt, road, and bare landscapes were $62.66,0.56$, and $1.23 \mathrm{~mm}$, respectively. These findings indicated that the urban greenbelt landscape is an important dew deposition site. The proportions of greenbelt, road, and bare land landscapes in the Changchun City were $36.5 \%, 16.68 \%$, and $0.78 \%$, respectively (General plans for the utilization of land in the Changchun City (2006-2020)). The annual dewfall of 
Changchun was $22.98 \mathrm{~mm}$ in 2016 according to Formula 6 in Section 2.2.

\subsection{Dew intensity and dewfall in different ecosystems}

As shown in Tab. 1, deserts, islands, rainforests, farmlands, and urban regions all exhibited dew condensation in different degrees. This dew intensity or dewfall was comparable with results found in other areas in the world (Tab. 1). The dew intensity in rainforests was frequent and far heavier than in other ecosystems. The dew intensity in each ecosystem, in decreasing order, was rainforest, farmland, desert, urban, wetland, and grassland.

Plants were dense and the transpiration was strong in the rainforest. High relative humidity enabled the average dew intensity in each canopy to reach $1.36 \mathrm{~mm}$. The highest and lowest canopies could reach 0.67 and 0.28 $\mathrm{mm}$, respectively [13]. As to the farmland ecosystem, the dewfall in a paddy field was significantly higher than that in the dry field due to the higher relative humidity of the paddy field [6]. A large difference in dewfall existed among different crop varieties. The desert area has a large temperature difference between day and night, which could be prone to condensation during summer and autumn. For instance, dewfall was $127.94-161\left(\mathrm{~g} / \mathrm{m}^{2}\right) / \mathrm{d}$ in August in the desert of North Area of Shaanxi [22]. Dew condensation is an important source of local groundwater and ranks second to rainfall and accounts for approximately $10 \%$ of annual rain. Differences in time, soil quality, region, meteorological condition, and underground water depth could lead to different nightly dew amounts. In the experiment of dew condensation in the dune surface of northwest region, the dew intensity was $0.01-0.06 \mathrm{~mm} / \mathrm{d}$ in the $10-16 \mathrm{~cm}$ dry sand layer in mid-September and was $0.01-0.31 \mathrm{~mm} / \mathrm{d}$ in the $20-30 \mathrm{~cm}$ wet sand layer at the corresponding time [12]. In an urban ecosystem, the difference in dew intensity in various functional areas was obvious. Ye et al. stated that the highest mean dew intensity in the urban area was observed in the forest landscape $(0.034 \mathrm{~mm} / \mathrm{night})$, followed by the industrial landscape $(0.022 \mathrm{~mm} / \mathrm{night})$, the commercial landscape $(0.013 \mathrm{~mm} /$ night $)$, and the residential landscape $(0.009 \mathrm{~mm} /$ night $)$ [20]. In Vancouver $\mathrm{BC}$, the dew frequency in city was close to the suburbs [23]. Dew intensity was $0.11-0.13 \mathrm{~mm}$ in a grassy landscape, whereas it was $0.07-0.09 \mathrm{~mm}$ in the town [24]. Dew was collected using standard passive dew condensers on a rooftop in southwest Morocco, which has an annual accumulated dewfall of $18.85 \mathrm{~mm}$ [17]. The condensation of dew in the city was considerable. Annual dewfall in urban ecosystems was more than twice that in wetland areas. Dew intensity was higher in wetlands, but the $L A I$ (1.3) in wetlands was lower than that in urban (5.0) areas. $L A I$ was the main factor that affected dewfall [11]. The same result was found by He, who reported dew formation on the meadow surface instead on the soil surface, as well as significant differences in the dewfall between normal meadows and degraded crust surfaces in the Qinghai-Tibet Plateau [10]. Thus, plants are the most important factors in vapor condensation.

Table 1 Dewfall in different ecosystems

\begin{tabular}{|c|c|c|c|c|}
\hline Type & Place & Dew intensity $(\mathrm{mm} / \mathrm{d})$ & Annual dewfall $(\mathrm{mm} / \mathrm{y})$ & Reference \\
\hline \multirow{8}{*}{ Urban } & Changchun & $\begin{array}{c}0.008 \text { to } 0.23 \\
0.098 \text { (Average) }\end{array}$ & 22.98 & This study \\
\hline & Forest landscape, Guangzhou, China & 0.034 (Average) & & \multirow{4}{*}[20]{} \\
\hline & Industrial landscape, Guangzhou, China & 0.022 (Average) & & \\
\hline & Commercial landscape, Guangzhou, China & 0.013 (Average) & & \\
\hline & Residential landscape, Guangzhou, China & 0.009 (Average) & & \\
\hline & Downtown, Vancouver, BC, Canada & 0.07 to 0.09 & & {$[24]$} \\
\hline & Suburb, Vancouver, BC, Canada & 0.11 to 0.13 & & [23] \\
\hline & Mirlefe, Morocco & & 18.85 & {$[17]$} \\
\hline \multirow{4}{*}{ Farmland } & Paddy, Sanjiang Plain, China & 0.03 to 0.13 & 26.2 to 31.4 & {$[6]$} \\
\hline & Soybean, Sanjiang Plain, China & 0.01 to 0.09 & 10 to 15 & {$[25]$} \\
\hline & Wheat, Luancheng, China & 0.21 & & \multirow{2}{*}[1]{} \\
\hline & Cornfield, Luancheng, China & 0.13 & & \\
\hline \multirow{2}{*}{ Island } & Ajaccio, France & 0.036 to 0.070 & 8.4 to 9.8 & {$[5]$} \\
\hline & Dalmatian, Croatia & 0.001 to 0.592 & 9.3 to 20 & [26] \\
\hline \multirow{3}{*}{ Desert } & Kothara, India & 0.004 to 0.240 & 6.3 to 8.9 & [27] \\
\hline & Nevada, USA & & 14 (estimation) & \multirow{2}{*}[28]{} \\
\hline & Utah, USA & & 29 (estimation) & \\
\hline Rainforest & Xishuangbanna, China & 1.36 & 89.4 & [13] \\
\hline Wetland & Sanjiang Plain, China & 0.02 to 0.12 & 8.4 to 11.12 & {$[11]$} \\
\hline \multirow{3}{*}{ Grassland } & Qinghai-Tibet Plateau (normal) & 0.002 to 0.22 & & \multirow{2}{*}[10]{} \\
\hline & Qinghai-Tibet Plateau (degraded) & 0.05 & & \\
\hline & Luancheng, China & 0.10 & & [1] \\
\hline
\end{tabular}

\section{Conclusion}

This study proposed a novel method for monitoring and calculating dew amount to calculate the vapor condensation input of urban ecosystems at night and reveal the effects of road hardening on surface water circulation. Combined with the different underlying surface dew condensation phenomena in urban ecosystems (Changchun, China) and based on monitoring typical underlying surfaces (greenbelt, bare, and road landscapes), the different underlying surface dew intensities were clarified and the factors affecting dew condensation were analyzed. The main conclusions are obtained as follows: 
(1) A total of 129 dew days are observed in Changchun City, which account for $61.4 \%$ of the frostfree period. Greenbelt landscape is the main area of dew condensation in urban ecosystems. Dewfall amounts in greenbelt landscape in July and August are 17.79 and $22.36 \mathrm{~mm}$, which account for $13.67 \%$ and $18.56 \%$ of the rainfall in the same period, respectively. Increasing the proportion of greenbelt landscapes in urban ecosystems can help the migration of water vapor to the surface interface at night.

(2) Dew intensities in urban areas differ among landscapes. The highest dew intensity is observed in the greenbelt landscape, followed by the road landscape, then the bare landscape $(P<0.01)$. The dew intensities in July, August, and September are significantly higher than in other months in greenbelt landscapes $(P<0.01)$. The highest dew intensity in road landscapes is in July $(P<$ $0.01)$. The dew intensity in bare landscapes among months has no significant differences $(P>0.05)$. Relative humidity may be the most important meteorological factor for the dew intensity in urban areas. $L A I$ is the determining factor of annual dewfall in different landscapes.

(3) The dewfall levels in the greenbelt, road, and bare landscapes are $62.66,0.56$, and $1.23 \mathrm{~mm}$, respectively. The annual dewfall in the Changchun City is $23.23 \mathrm{~mm}$ in the experimental period according to the land type proportion.

The urban dew-monitoring method proposed in this study is generally simple and maneuverable. The monitors are easy to prepare and the method is suitable for monitoring different landscapes in different dew condensation periods. This study complements and completes the method for monitoring dew with uneven covering. The input of vapor condensation in urban ecosystem at night lays the foundation for the comprehensive discussion of the function and significance of wet deposition. However, this method is strict to monitor collection time in the morning and evening. In the future study, related meteorological factors should be used to build a model, or an online monitoring method should be used to reduce manual operation. Such study will improve the understanding of near surface dew condensation time and intensity.

\section{Acknowledgement}

This work was supported by the National Nature Science Foundation of China (project no. 41401229), Science and Technology Program of Jilin Province (project no. 201705200827JH) and Foundation of Education Bureau of Jilin Province (project no. 2016161) and Special S\&T Project on Treatment and Control of Water Pollution (project no. 2010ZX07320-003).

\section{$5 \quad$ References}

[1] Wen, X. F.; Lee, X. H.; Sun, X. M.; Wang, J. L.; Hu, Z. M.; Li, S. G.; Yu, G. R. Dew water isotopic ratios and their relationships to ecosystem water pools and fluxes in a cropland and a grassland in China. // Oecologia. 168, 2(2012), pp. 549-561.

https://doi.org/10.1007/s00442-011-2091-0
[2] Kidron, G. J.; Starinsky, A. Chemical composition of dew and rain in an extreme desert (Negev): Cobbles serve as sink for nutrients. // Journal of Hydrology. 420-421, (2012), pp. 284-291. https://doi.org/10.1016/j.jhydrol.2011.12.014

[3] Xu, Y. Y.; Yan, B. X.; Zhu, H. Leaf dew contributes nutrients to paddies and improves rice growth. // Acta Agriculturae Scandinavica, Section B-Plant Soil Science. 63, 2(2013), pp. 97-106. https://doi.org/10.1080/09064710.2012.725766

[4] Rubio, M. A.; Lissi, E.; Herrera, N.; Pérez, V.; Fuentes, N. Phenol and nitrophenols in the air and dew waters of Santiago de Chile. // Chemosphere. 86, 10(2012), pp. 10351039. https://doi.org/10.1016/j.chemosphere.2011.11.046

[5] Beysens, D.; Muselli, M.; Nikolayev, V.; Narhe, R.; Milimouk, I. Measurement and modelling of dew in island, coastal and alpine areas. // Atmospheric Research. 73, 12(2005), pp. 1-22. https://doi.org/10.1016/j.atmosres.2004.05.003

[6] Xu, Y. Y.; Yan, B. X.; Wang, L. X. A Research of Dewfall in Paddy. // Scientia Agricultura Sinica. 44, 3(2011), pp. 524-530.

[7] Maestre-Valero, J. F.; Martin-Gorriz, B.; Martínez-Alvarez, V. Dew condensation on different natural and artificial passive surfaces in a semiarid climate. // Journal of Arid Environments. 116, (2015), pp. 63-70. https://doi.org/10.1016/j.jaridenv.2015.02.002

[8] Meng, Y.; Wen, X. F. Characteristics of dew events in an arid artificial oasis cropland and a sub-humid cropland in China. // Journal of Arid Land. 8, 3(2016), pp. 399-408. https://doi.org/10.1007/s40333-016-0006-y

[9] Liu, W. J.; Liu, W. Y.; Li, P. J.; Duan, W. P.; Li, H. M. Dry season water uptake by two dominant canopy tree species in a tropical seasonal rainforest of Xishaugnbanna, SW China. // Agricultural and Forest Meteorology. 150, 3(2010), pp. 380-388. https://doi.org/10.1016/j.agrformet.2009.12.006

[10] He, S. Y.; Richards, K. The role of dew in the monsoon season assessed via stable isotopes in an alpine meadow in Northern Tibet. // Atmospheric Research. 151, (2015), pp. 101-109. https://doi.org/10.1016/j.atmosres.2014.02.014

[11] Xu, Y. Y.; Yan, B. X.; Luan, Z. Q.; Zhu, H. Dewfall variation by large-scale reclamation in Sanjiang Plain. // Wetlands. 32, (2012), pp. 783-790. https://doi.org/10.1007/s13157-012-0314-8

[12] Cao, W. B.; Wan, L.; Zhou, X. A preliminary study of the formation mechanism of condensation water and its effects on the ecological environment in northwest China. // Hydrogeology and Engineering Geology. 30, 2(2003), pp. 6-10.

[13] Liu, W. J.; Zeng, J. M.; Wang, C. M.; Li, H. M.; Duan, W. $P$. On the relationship between forests and occult precipitation (dew and fog precipitation). // Journal of Natural Resources.16, 6(2001), pp. 517-575.

[14] Beysens, D.; Pruvost, V.; Pruvost, B. Dew observed on cars as a proxy for quantitative measurements. // Journal of Arid Environments. 135, (2016), pp. 90-95. https://doi.org/10.1016/j.jaridenv.2016.08.014

[15] Arias-Torres, J. E.; Flores-Prieto, J. J. Winter dew harvest in Mexico City. // Atmosphere. 7, 1(2016), pp. 2-13. https://doi.org/ 10.3390/atmos7010002

[16] Talaee, P. H.; Sabziparvar, A. A.; Tabari, H. Observed changes in relative humidity and dew point temperature in coastal regions of Iran. // Theoretical and Applied Climatology. 110, (2012), pp. 385-393. https://doi.org/10.1007/s00704-012-0630-1

[17] Lekouch, I.; Lekouch, K.; Muselli, M.; Mongruel, A.; Kabbachi, B.; Beysens, D. Rooftop dew, fog and rain collection in southwest Morocco and predictive dew modeling using neural networks. // Journal of Hydrology. 448-449, (2012), pp. 60-72. 
https://doi.org/10.1016/j.jhydrol.2012.04.004

[18] Gałek, G.; Sobik, M.; Błaśa, M.; Polkowska, Ż.; CichałaKamrowska, K.; Wałaszek, K. Dew and hoarfrost frequency, formation efficiency and chemistry in Wroclaw, Poland. // Atmospheric Research. 151, 1(2015), pp. 120129. https://doi.org/10.1016/j.atmosres.2014.05.006

[19] Xu, Y. Y.; Zhu, H.; Tang, J. The effects of haze on dew quality in the urban ecosystem of Changchun, Jilin Province, China. // Environmental Monitoring and Assessment. 188, 2(2016), article ID 02832. https://doi.org/10.1007/s10661-016-5131-8

[20] Ye, Y. H.; Zhou, K.; Song, L. Y.; Jin, J. H; Peng, S. L. Dew amounts and its correlations with meteorological factors in urban landscapes of Guangzhou, China. // Atmospheric Research. 86, 1(2007), pp. 21-29. https://doi.org/10.1016/j.atmosres.2007.03.001

[21] Xu, Y. Y.; Yan, B. X.; Tang, J. The effect of climate change on variations in dew amount in a paddy ecosystem of the Sanjiang Plain, China. // Advances in Meteorology. 2015, (2015), article ID 793107. https://doi.org/10.1155/2015/793107

[22] Zhang, J. S.; Wu, Y. Q.; Li, Z. Test and Research of Precipitation Intercepted by Groundwater and Condensation in Desert Pool of North Area of Shaanxi. // Journal of Soil and Water Conservation. 19, 5(2005), pp. 124-126.

[23] Richards, K. Observation and simulation of dew in rural and urban environments. // Progress in Physical Geography. 28, 1(2004), pp. 76-94. https://doi.org/10.1191/0309133304pp402ra

[24] Richards, K. Urban and rural dewfall, surface moisture, and associated canopy-level air temperature and humidity measurements for Vancouver, Canada. // Boundary-Layer Meteorology. 114, 1(2005), pp. 143-163. https://doi.org/10.1007/s10546-004-8947-7

[25] Yan, B. X.; Xu, Y. Y.; Wang, L. X. Dew condensation rules in farmland ecosystem in Sanjiang Plain. // Acta Ecologica Sinica. 30, 20(2010), pp. 5577-5584.

[26] Muselli, M; Beysens, D; Mileta, M.; Milimouk, I. Dew and rain water collection in the Dalmatian coast, Croatia. // Atmospheric Research. 92, 4(2009), pp. 455-463. https://doi.org/10.1016/j.atmosres.2009.01.004

[27] Sharan, G.; Beysens, D.; Milimouk, M. I. A study of dew water yield on Galvanized iron roofs in Kothara(NorthWest India). // Journal of Arid Environments. 69, 2(2007), pp. 259-269. https://doi.org/10.1016/j.jaridenv.2006.09.004

[28] Malek, E.; Giles, B.; Mccurdy, G. Dew contribution to the annual water balances in semi-arid desert valleys. // Journal of Arid Environments. 42, 2(1999), pp. 71-80. https://doi.org/10.1006/jare.1999.0506

\section{Authors' addresses}

\section{Xu Yingying, Ph.D.}

Room E414, Key Laboratory of Songliao Aquatic Environment, Ministry of Education, Jilin Jianzhu University, No. 5088 Xin Cheng Road, Changchun, 130118, Jilin Province, P. R. China E-mail: xuyingying.1019@aliyun.com

\section{Zhu Hui, Ph.D., Associate Professor}

(Corresponding author)

Room 412, Key Laboratory of Wetland Ecology and Environment, Northeast Institute of Geography and Agroecology, Chinese Academy of Sciences, No. 4888 Shengbei Street, Changchun, 130102, Jilin Province, P. R. China

E-mail: zhuhui@iga.ac.cn

\section{Sun Xuejing, Ph.D., Associate Professor}

Room A307, Key Laboratory of Songliao Aquatic Environment, Ministry of Education, Jilin Jianzhu University, No. 5088 Xin Cheng Road, Changchun, 130118, Jilin Province, P. R. China E-mail: 289632769@qq.com
Meng Qingling, Ph.D., Associate Professor

1) Room E414, Key Laboratory of Songliao Aquatic Environment, Ministry of Education, Jilin Jianzhu University, No. 5088 Xin Cheng Road, Changchun, 130118, Jilin Province, P. R. China

2) School of Geosciences, University of Edinburgh, Drummond Street, Edinburgh EH8 9XP, G12 8QQ, U.K

E-mail:273501163@qq.com 